\title{
PENGARUH PENGETAHUAN ORANG TUA TENTANG ORTODONSI PREVENTIF DENGAN PERILAKU PENCEGAHAN MALOKLUSI PADA GIGI ANAK
}

\author{
M Yaqiudin Aditya $a^{\star}$, Moh. Baehaqi ${ }^{* *}$, Rahmawati Sri Praptiningsih ${ }^{* *}$
}

\begin{abstract}
Keywords:

knowledge, behavior, education

Background: Malocclusion is abnormal occlusion which signed the unsimetric position of its teeth that caused by genetic factor, unappropiate development, bad habit and malnutrition. The children who got malocclusion problem doesn't need any attention because children usually still lack of responsbility to take care the dental problem. That's why the role of parents is very needed. Parents knowledge about preventive ortodensi can make easier to prevent children malocclusion. Purpose: The purpose of this research is to know the influence of parents knowledge about preventive ortodensi to prevent children malocclusion. Method: This research using analitic observational with survey cross sectional method. Data comes from kuisioner. The parents knowledge means everything about the prevention of malocclusion, meanwhile preventive action is the action to handle malocclusion itself. wllcoxon experiment is used for analitical tool with $p<0.05$. Result: The result shown that the parents knowledge about ortodensi will appear better to parents who got the bachelor or diploma degree $(65.9 \%)$. And preventive action for malocclusion also shown better from parents with bachelor or diploma degree also (71.05\%). Conclusion: The conclusion is the influence of parents knowledge about malocclusion prevention in children teeth with level of $(p=0.001)$ with confident level $90 \%$.
\end{abstract}

\section{PENDAHULUAN}

Maloklusi merupakan masalah gigi terbesar kedua di Indonesia, 80\% dari penduduk Indonesia mengalami maloklusi 1. Maloklusi adalah oklusi abnormal yang ditandai dengan tidak sesuainya hubungan antar lengkung atau anomali dalam posisi gigi ${ }^{2}$. Penyebab maloklusi diantaranya adalah faktor keturunan, perkembangan dan pertumbuhan yang salah, kebiasaan buruk dan malnutrisi ${ }^{3}$. Anak yang mengalami maloklusi merasa tidak membutuhkan perawatan dikarenakan motivasi anak usia sekolah untuk merawat giginya masih sangat kurang sehingga peran orang tua sangat dibutuhkan dalam usia tumbuh kembang anak ${ }^{4}$. Sebagian besar orang mengetahui akan perlunya perawatan ortodonsi untuk mencegah terjadinya maloklusi akan tetapi hanya sebagian kecil yang mengetahui penyebab serta tanda-tanda akan timbulnya maloklusi. Sehingga potensi timbulnya maloklusi masih tetap tinggi ${ }^{5}$.

\section{METODE}

Penelitian observasional analitik dengan rancangan cross sectional dilakukan pada 75 orang tua siswa SDN Sumbergirang kabupaten Rembang yang dipilih secara simple random sampling. Penelitian dilakukan pada bulan november-desember 2014.

Pengetahuan orang tua tentang ortodonsi preventif adalah segala informasi yang diketahui dan dimengerti oleh orang tua tentang hal-hal yang berkaitan dengan perawatan pencegahan terhadap susunan 
gigi. Skala pengukuran yang Interval. Dengan kriteria baik (skor 66,7 - 100\%(, cukup (skor $33,4-66,6 \%$ ), kurang (skor 0-33,3\%). Perilaku pencegahan maloklusi pada gigi anak adalah respon atau tindakan orang tua yang dilakukan guna mempertahankan pertumbuhan dan perkembangan yang normal agar susunan gigi anak tetap pada susunan yang normal. Skala pengukuran yang digunakan adalah Interval. Dengan kriteria skor Baik (skor 75 $100 \%$ ) cukup (skor 50 - 74,9\%), Kurang (skor 0-49,9\%). Uji wilcoxon digunakan sebagai alat analisis pada tingkat kemaknaan $p<0,05$.

\section{HASIL PENELITIAN}

Distribusi pengetahuan ortodonsi preventif responden berdasarkan kelompok usia terdapat pada tabel 1. Sedangkan distribusi perilaku responden terhadap pencegahan maloklusi pada gigi anak berdasarkan kelompok usia terdapat pada tabel 2. Tabulasi silang pengetahuan dengan tingkat pendidikan pada tabel 3 .

Tabel 1. Tabulasi silang antara pengetahuan dengan kelompok usia responden

\begin{tabular}{lrrrrr}
\hline & \multicolumn{4}{c}{ Kelompok usia } & \\
& $27-35$ & $36-43$ & $44-52$ & Total \\
\hline Pengetahuan Baik & 19 & 18 & 7 & 44 \\
& 12 & 12 & 7 & 31 \\
\hline Cukup & 31 & 30 & 14 & 75
\end{tabular}

Tabel 2. Tabulasi silang antara perilaku dengan kelompok usia responden

Kelompok usia

\begin{tabular}{llrrrr} 
& & $27-35$ & $27-35$ & $27-35$ & \multicolumn{2}{l}{ Total } \\
\hline Perilaku & Baik & 19 & 13 & 6 & 38 \\
& Cukup & 16 & 12 & 6 & 34 \\
& Kurang & 2 & 1 & - & 3 \\
\hline Total & & 37 & 26 & 12 & 75 \\
\hline
\end{tabular}

Tabel 3. Tabulasi silang antara pengetahuan dengan tingkat pendidikan responden

\begin{tabular}{llrrrr}
\hline & & \multicolumn{3}{c}{ Pendidikan } & \multicolumn{2}{l}{ Total } \\
& & SMA & Diploma & Sarjana & \multicolumn{2}{l}{ Th } \\
\hline Pengetahuan & Baik & 15 & 8 & 21 & 44 \\
& Cukup & 25 & 0 & 6 & 31 \\
\hline Total & & 40 & 8 & 27 & 75 \\
\hline
\end{tabular}


Tabel 1 menunjukkan pengetahuan responden hanya ada pada tingkat baik dan cukup, terdapat 31 responden pada kelompok usia 27-35 tahun, 19 diantaranya memiliki kriteria pengetahuan baik dan sisanya kriteria cukup. Sebanyak 30 responden berusia antara 36-43 tahun, 18 diantaranya memiliki pengetahuan baik dan sisanya cukup. Sebanyak 14 responden berusia antara 44-52 tahun, 7 diantaranya memiliki pengetahuan baik dan lainnya cukup. Kelompok usia memberikan gambaran pengetahuan responden merata antara usia muda dan tua.

Berdasarkan tabel 2, terdapat 37 responden pada kelompok usia 27-35 tahun, 19 diantaranya memiliki kriteria perilaku baik, 16 responden perilaku cukup dan 2 sisanya kriteria kurang. Sebanyak 26 responden berusia antara 36-43 tahun, 13 diantaranya memiliki perilaku baik, 12 responden perilaku cukup dan 1 sisanya kurang. Sebanyak 12 responden berusia antara 44-52 tahun, 6 diantaranya memiliki perilaku baik dan lainnya cukup. Kelompok usia memberikan gambaran perilaku responden merata antara usia muda dan tua.

Hasil pengelompokan data pengetahuan berdasarkan tingkat pendidikan pada tabel 3, responden berpendidikan SMA yang berpengetahuan ortodonsi preventif baik didapatkan sebanyak 15 responden dan kriteria cukup sebanyak 25 responden. Responden berpendidikan tingkat diploma yang berpengetahuan ortodonsi preventif baik didapatkan sebanyak 8 responden dan tidak didapatkan responden dengan kriteria cukup. Responden dengan pendidikan tingkat sarjana yang berpengetahuan ortodonsi preventif baik didapatkan sebanyak 21 responden dan yang cukup sebanyak 6 responden. Kriteria pengetahuan baik didominasi oleh tingkat pendidikan sarjana sedangkan kriteria cukup didominasi oleh responden dengan tingkat pendidikan SMA.

Tabel 4 menunjukkan distribusi perilaku pencegahan maloklusi responden berdasarkan pendidikan. Hasil pengelompokan data perilaku pencegahan maloklusi berdasarkan tingkat pendidikan, responden dengan tingkat pendidikan SMA yang memiliki perilaku pencegahan maloklusi baik sebanyak 11 responden, kriteriacukup sebanyak27 responden dan kriteria kurang sebanyak 2 responden. Responden dengan tingkat pendidikan diploma yang memiliki perilaku pencegahan maloklusi dengan kriteria baik sebanyak 6 responden, kriteria cukup sebanyak 2 responden dan tidak ditemukan perilaku responden dalam mencegah maloklusi dengan kriteria kurang. Responden dengan tingkat pendidikan sarjana yang memiliki perilaku pencegahan maloklusi baik sebanyak 21 responden, kriteria cukup sebanyak 5 responden dan kriteria kurang sebanyak 1 responden. Kriteria perilaku pencegahan maloklusi baik didominasi oleh tingkat pendidikan sarjana sedangkan kriteria cukup didominasi oleh responden dengan tingkat pendidikan SMA.

Tabel 4. Tabulasi silang antara perilaku dengan tingkat pendidikan responden

Pendidikan

SMA Diploma Sarjana Total

\begin{tabular}{llrrrr}
\hline Perilaku & Baik & 11 & 6 & 21 & 38 \\
& Sedang & 27 & 2 & 5 & 34 \\
& Kurang & 2 & 0 & 1 & 3 \\
\hline Total & & 40 & 8 & 27 & 75
\end{tabular}


Tabel 5. Uji Wilcoxon

\begin{tabular}{lr}
\hline & $\begin{array}{c}\text { Perilaku - } \\
\text { Pengetahuan }\end{array}$ \\
\hline$Z$ & $-2.714^{\mathrm{b}}$ \\
(p) Sigfikansi & .007 \\
\hline
\end{tabular}

Uji Wilcoxon ditemukan bahwa nilai $\mathrm{p}$ adalah 0,007 . Berarti bahwa $p<0,05$ sehingga menunjukkan bahwa terdapat pengaruh antara pengetahuan tentang ortodonsi preventif dengan perilaku pencegahan maloklusi pada gigi anak.

\section{DISKUSI}

Rentang usia responden memberikan hasil yang seimbang antara tingkat pengetahuan ortodonsi preventif dengan kriteria baik dan kriteria cukup serta perilaku responden terhadap pencegahan maloklusi juga merata pada kriteria baik dan kriteria cukup. Data tersebut memberikan asumsi bahwa tidak terdapat perbedaan antara pengetahuan dan perilaku responden pada kelompok usia muda dan usia tua.

Faktor usia merupakan pengaruh terhadap pembentukan pola pikir serta daya tangkap seseorang. Distribusi pengetahuan dan perilaku responden merata pada kriteria baik dan sedang bila dilihat dari kelompok usia mununjukkan bahwa pada usia madya, individu berperan aktif dalam kehidupan sosial termasuk didalamnya adalah proses belajar, serta lebih banyak menyesuaikan diri mempersiapkan usia tua sehingga pada usia madya selalu memperbaharui informasi dan semakin tua semakin banyak informasi yang dijumpai akhirnya semakin banyak hal yang dikerjakan sehingga menambah pengetahuannya ${ }^{6}$.

Pengetahuan tentang ortodonsi preventif mayoritas baik $(58,7 \%)$ terlihat pada hasil penelitian yang telah dilakukan. Sebagian besar responden memiliki pengetahuan baik terdapat pada tingkat pendidikan diploma dan sarjana. Pengetahuan tentang ortodonsi preventif dengan kriteria sedang didominasi oleh responden dengan tingkat pendidikan SMA. Tingkat pengetahuan dipengaruhi oleh tingkat pendidikan ${ }^{6}$. Semakin tinggi pendidikan seseorang semakin mudah pula mereka menerima informasi, dan pada akhirnya semakin banyak pula pengetahuan yang dimilikinya ${ }^{7}$. Pengetahuan tentang kesehatan gigi seseorang dipengaruhi oleh karakteristik individu ditinjau dari tingkat pendidikan dan lingkungan tempat tinggalnya ${ }^{8}$. Tingkat pendidikan dapat menumbuhkan motivasi untuk mencerna informasi, informasi kesehatan gigi dan mulut tersebut dapat diperoleh dari interaksi dalam keluarga, sekolah dan masyarakat yang merupakan bagian dari proses pendidikan kesehatan gigi dan mulut 9 .

Sebagian besar responden memiliki perilaku pencegahan maloklusi yang baik, terdapat perbedaan pada kelompok dengan tingkat pendidikan sarjana dengan SMA, pada kelompok pendidikan sarjana perilaku pencegahan maloklusi pada gigi anak lebih baik dibanding dengan kelompok pendidikan SMA. Ditinjau dari teori Lawrence Green, terbentuknya perilaku individu dipengaruhi oleh faktor tingkat pendidikan ${ }^{10}$. Perilaku tersebut menimbulkan respon terhadap masalah yang dihadapi berupa persepsi dan tindakan nyata yang dapat menanggulangi masalah it. Masalah yang dihadapi tersebut jika berupa kelainan atau penyakit maka akan timbul respon untuk menanggulangi atau mencegahnya dan tindakan tersebut dikatakan sebagai perilaku pencegahan terhadap suatu kelainan atau penyakit/health prevention behavior ${ }^{6}$.

Dari hasil uji Wilcoxon yang telah dilakukan diatas, dapat dilihat bahwa terdapat pengaruh signifikan antara pengetahuan orang tua tentang ortodonsi preventif terhadap perilaku pencegahan maloklusi pada gigi anak. Didapatkan hasil bahwa pengetahuan responden tentang ortodonsi preventif pada tingkat cukup dan baik. Perilaku responden dalam mencegah maloklusi juga mayoritas pada tingkat cukup dan tingkat baik.

Pengetahuan merupakan domain yang paling essensial dalam membentuk perilaku 
6. Pengetahuan yang cukup baik tentang kesehatan gigi dan mulut diperlukan untuk menumbuhkan perilaku yang baik terhadap perawatan gigi yang bersifat menetap ${ }^{10}$. Orang tua dengan tingkat pendidikan yang tinggi akan cenderung menggali informasi serta memahami dengan lebih baik tentang masalah gigi yang ada kemudian akan meningkatkan partisipasi perawataan gigi anak dan menimbulkan perilaku yang positif terhadap perawatan gigi anak ${ }^{10}$.

Pengetahuan orang tua tentang kesehatan gigi dan mulut baik itu preventif, kuratif maupun rehabilitatif diperoleh dari informasi yang diterima dari interaksi sosial dan kemudian menjadi stimulus yang akan membentuk perilaku individu dalam menjaga kesehatan gigi. Tidak semua orang tua dapat menerima informasi tersebut dengan mudah, hal itu berkaitan dengan tingkat pendidikan yang dimiliki oleh orang tua, dengan tingkat pendidikan yang tinggi orang tua akan cenderung menggali informasi serta memahami dengan lebih baik tentang masalah gigi yang ada kemudian akan meningkatkan partisipasi perawataan gigi anak ${ }^{10}$.

\section{KESIMPULAN}

Orang tua siswa SDN 1 Sumbergirang kabupaten Rembang memiliki pengetahuan baik tentang ortodonsi preventif serta memiliki perilaku yang baik dalam mencegah gigi maloklusi pada gigi anak. Terdapat pengaruh yang signifikan antara pengetahuan orang tua tentang ortodonsi preventif dengan perilaku pencegahan maloklusi pada gigi pada orang tua siswa SDN 1 Sumbergirang kabupaten Rembang.

\section{DAFTAR PUSTAKA}

1. Achmad, H., Penanganan delayed eruption karena impaksi gigi insisivus sentralis kiri dengan surgical exposure pada anak. Journal of Dentofasial. 8(1): hal. 48-54. 2009.

2. Harty, F.J, \& Ogston, R. Kamus Kedokteran Gigi. alih bahasa Narlan S., Jakarta: Penerbit EGC, hal. 189. 2001.

3. Proffit, W.R., \& Fields, H.W., Contemporary Orthodontics (3rd ed). St Louis: Mosby. P.2-4. 2000

4. Ngom, P.I., dkk. Orthodontic treatment need and demand in Senegalese school children aged 12-13 years. Angle Orthodontist: 77(2): 323-330. 2007

5. Danaei, S.M, Assesment of parental awareness about malocclusion in Shiraz, Islamic Republic of Iran. Shiraz: Pubmed. 17(7). 599-603. 2011.

6. Notoatmodjo, S., Pendidikan dan Perilaku Kesehatan. Jakarta: Rineka Cipta. 2007.

7. Mubarak., Promosi Kesehatan. Yogyakarta: Graha ilmu. 2007.

8. Yulianti, R.P., Hubungan antara Pengetahuan Orang Tua tentang Kesehatan Gigi dan Mulut dengan Kejadian Karies Gigi Pada Anak Di SDN V Jaten Karanganyar. FIK UMS, 2010.

9. Herijulianti, E. Dkk., Pendidikan Kesehatan Gigi. Jakarta: Penerbit EGC. 1993.

10. Sumanti, V., Faktor yang berhubungan dengan partisipasi orang tua dalam perawatan kesehatan gigi anak di Puskesmas Tegallalang I. Gianyar. Public Health and Preventive Medicine Archive. Vol 1. No.1. 2013. 